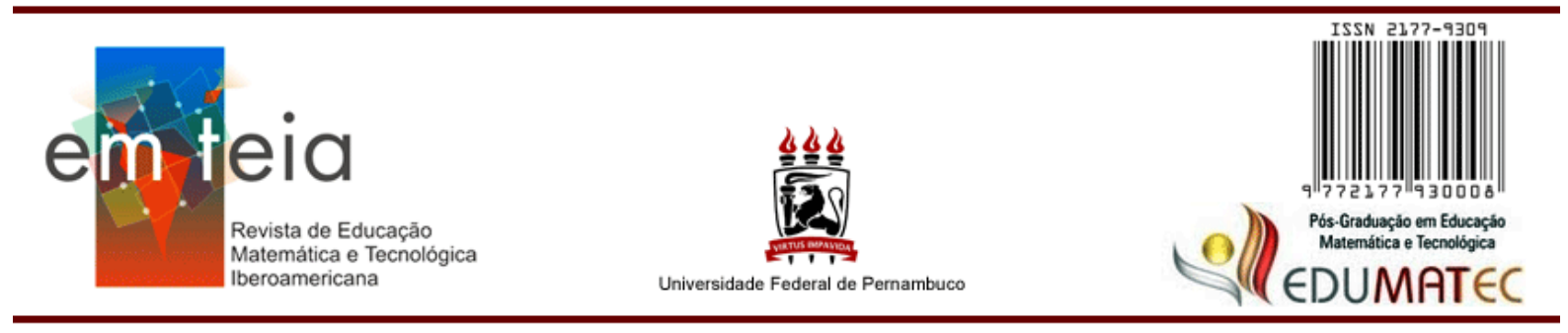

\title{
Criar histórias, narrar a vida e produzir audiovisualidades: Digital Storytelling na formação docente
}

\author{
Tania Lúcia Maddalena \\ Doutora em Educação pelo Proped/UERJ. \\ tlmaddalena@gmail.com \\ Vivian Martins \\ Professora do Instituto Federal do Rio de Janeiro. \\ vivian.martinst@gmail.com \\ Edméa Santos \\ Professora no Programa de Pós-graduação em Educação - Proped/UERJ. \\ edmeabaiana@gmail.com
}

\section{Introdução}

Durante a disciplina Tecnologias e Educação, da Licenciatura em Pedagogia da Universidade do Estado do Rio de Janeiro (UERJ), buscamos trabalhar a criação da Digital Storytelling na formação de professores, pensando a passagem de espectador para narrador/criador como fundamental para a socialização, a autoria e a implicação dos praticantes em formação na educação superior. Nesse desafio, houve a busca pela criação de audiovisualidades como experiência, com a finalidade de fortalecer o protagonismo e as múltiplas vivências ao longo da formação docente.

Para a criação dos vídeos foram considerados os passos instituídos por Lambert (2009) na utilização e no desenvolvimento da metodologia da Digital Storytelling para relatos de vida com narrativas pessoais. Partilhando da compreensão de que essas narrativas são um processo de reconstrução e invenção de si e da opção pelo formato audiovisual para as suas produções, procuramos compreender os novos vídeos e a produção de audiovisualidades na cultura contemporânea. Nesse sentido, o audiovisual se destaca como possibilidade de significação, experimentação, imaginação e de invenção.

Como método de pesquisa, tem-se a pesquisa-formação na cibercultura como uma opção para a produção de conhecimento na cultura contemporânea, em que praticantes estejam em interação horizontal, ou seja, na relação em que todos são vistos como potenciais 
formadores e pesquisadores, em contexto de educação online, com objetos de pesquisa que proporcionem experiências e vivências significativas, assim como pontua Josso (2004, p. 25):

A originalidade da metodologia da pesquisa-formação situa-se, em primeiro lugar, em nossa constante preocupação com que os autores de narrativas consigam atingir uma produção de conhecimentos que tenha sentido para eles e que eles próprios se inscrevam num projeto de conhecimento que os institua como sujeitos.

A cibercultura é contexto e dispositivo de pesquisa, e tendo em vista a particularidade do conhecimento fazer sentido para os praticantes, não poderíamos estar descontextualizados de suas práticas cotidianas. Também é dispositivo, com a Digital Storytelling e a pergunta disparadora: como a tecnologia digital chegou na minha vida? Como proposta tem-se a produção de vídeos de 4 minutos, ficcionais ou não, possibilitando a narrativa de si pelos praticantes ciberculturais. Duas produções foram apresentadas na ultima seção do texto: "O avanço da tecnologia: história da Renata" e "Digital Storytelling na UERJ" para relatar os resultados da pesquisa e a implicação das praticantes no desenvolvimento dos vídeos.

O presente texto foi desenvolvido em tópicos específicos: na seção 1, esta introdução, apresentando a pesquisa e as opções metodológicas; na seção 2, a apresentação do digital storytelling como uma prática de contar histórias digitais em hipermídia; na seção 3 , o entrelaçamento entre a criação audiovisual e a cultura contemporânea, com a reflexão sobre as audiovisualidades; na seção 4, princípios da pesquisa, com o método da pesquisa-formação na cibercultura; na seção 5, o relato do campo de pesquisa com a pergunta disparadora: "Como a tecnologia digital chegou na minha vida?"; e na seção 6, algumas considerações conclusivas com uma síntese dos conteúdos abordados.

\section{Digital Storytelling: contar histórias digitais na hipermídia}

A utilização do conceito Digital Storytelling teve início na década dos 90 nos EUA. Joe Lambert foi o primeiro autor a usar o termo e suas experiências de pesquisa com a narração de histórias e trajetórias pessoais ao longo de muitos anos o fizeram desenvolver a metodologia da Digital Storytelling que consiste em criar um vídeo breve, de até uns 4 minutos de duração, no qual prima o conteúdo narrativo. No vídeo, o narrador compartilha em 
formato audiovisual aspectos da sua história ou temática de interesse, utilizando diversos recursos digitais, como fotografias, imagens, música, vídeos, sons etc.

A metodologia da Digital Storytelling foi incluída por Lalueza, Crespo e Camps (2010) entre as três linhas de pesquisa emergentes relacionadas com a utilização das tecnologias da informação e comunicação (TIC) nos processos de socialização do indivíduo. Experiências que utilizam a Digital Storytelling em formato de vídeo como forma de expressão e autoria, desde idades precoces, na educação formal e não formal, na dinamização sociocultural, na intervenção terapêutica, no desenvolvimento cultural comunitário, demonstram como a passagem de estatuto de espectador para o de narrador é fundamental na socialização dos seres humanos (BRUNER, 1998). Os autores salientam que "as possibilidades abertas pelas TIC na construção de narradores serão, sem dúvida, um elemento fundamental nos estudos dos processos evolutivos do futuro" (LALUEZA e outros, 2010, p. 63).

Segundo Lambert (2009), toda narrativa digital em formato de vídeo costuma ter sete elementos principais: ponto de vista, pergunta dramática, conteúdo emocional, voz do narrador, trilha sonora, economia narrativa e ritmo da narração. Estes elementos podem ser classificados em duas fases da criação das narrativas: a fase de escrita e a fase de elaboração/edição posterior, obtendo como resultado um vídeo de entre 4 e 5 minutos de duração.

A fase de escrita inclui os seguintes elementos: ponto de vista, pergunta dramática, conteúdo emocional e economia narrativa. Quanto à fase de elaboração posterior, os elementos nela incluídos são o ritmo, a voz do narrador e a trilha sonora. O ponto de vista será determinado pelos motivos pelos quais o autor ou autores da narrativa querem contar uma história, o objetivo perseguido, a audiência que receberá e interpretará a narrativa e a mensagem a ser transmitida. No início da narrativa, o autor faz uma pergunta dramática, de modo direto ou indireto, para criar suspense e para chamar atenção da audiência.

O conteúdo emocional faz com que o interesse e a curiosidade da audiência aumentem gradativamente e cria uma maior empatia entre o autor ou autores e o receptor ou receptores. A voz do narrador ou dos narradores facilita a transmissão da mensagem por parte do autor ou autores. A trilha sonora, embora opcional, é um elemento complementar importante porque contribui para reforçar a mensagem, motivo pelo qual deve ser escolhida 
cuidadosamente para evitar um volume excessivo ou a presença de letra que possa interferir na compreensão da história.

Segundo Lambert (2009), a economia narrativa é outro elemento essencial, pois a sua função é evitar o excesso de informação, o que ajuda a audiência a concentrar a sua atenção na mensagem central da narrativa. Por último, o ritmo é um elemento que tem a ver não somente com a velocidade com que a história é contada, mas também com a velocidade e quantidade de imagens ou vídeos que aparecem em sincronia com a voz do narrador ou narradores. É muito importante que a narrativa digital tenha um ritmo apropriado, nem muito rápido nem muito lento, para que a narrativa seja compreensível e, ao mesmo tempo, interessante e divertida (MADDALENA; SEVILLA PAVÓN, 2015).

O principal interesse de Joe Lambert (2009) na utilização e no desenvolvimento da metodologia da Digital Storytelling em vídeo concentrou-se em narrativas pessoais. Seu trabalho caracteriza-se pelos relatos de vida com grupos focais em situações desfavoráveis. Assim, ao longo desses anos, o autor estudou o potencial da prática de narrar histórias digitais como um processo de reconstrução e invenção de si, sempre mantendo o formato audiovisual nas suas produções e cursos de formação sobre a metodologia. O processo de criação da Digital Storytelling serve bem à produção de um gênero de autorrepresentação e nesta prática reside seu potencial formativo.

Na sua obra "Digital Storytelling: A creador's guide to interactive entertainment", Miller (2008) distingue dois tipos de Digital Storytelling: um que a autora chama de "tradicionais", em que o autor-criador segue uma narrativa que expressa um produto final acabado, com as sequências da história fixas, em formato de vídeo curto. E um outro tipo, a Digital Storytelling interativa, que pode ser em maior ou menor grau de interatividade. Isto significa que o autor-criador mantém a trama da história em aberto, não possuindo a história uma linearidade e cronologia preconcebida. As histórias deste tipo podem ser modificadas pelos usuários que acessam a história, convertendo-se assim em coautores da mesma e podendo, até mesmo, definir o final ou finais possíveis da história narrada.

É importante esclarecer que a própria evolução da web proporcionou outras formas de compartilhamento e circulação dos vídeos e das histórias na internet. A metodologia da Digital Storytelling com as bases de Joe Lambert e pesquisadores do Storycenter da Califórnia é conhecida no mundo todo e mantém caraterísticas do tempo em que foi criada, nos anos 
90, com predominância da linguagem audiovisual sem a plasticidade da internet que temos na atualidade.

Hoje, com o desenvolvimento dos aplicativos móveis, os vídeos e microvídeos são utilizados em diversas redes sociais e plataformas para contar histórias, então, não podemos deixar de salientar que o formato audiovisual torna-se umas das linguagens mais utilizadas para contar histórias na contemporaneidade. Presenciamos uma expansão de "vídeos verticais" que antigamente não existiam e são provenientes do uso cotidiano do celular. A televisão e o computador são horizontais, a narrativa vertical está associada à forma em que nos comunicamos com os dispositivos móveis e não é uma forma considerada profissional, mas é uma prática cultural comum em nossos dias que modifica a forma de assistir e produzir vídeos.

Assim, a produção e o consumo de vídeos e microvídeos nos dispositivos móveis trouxeram novas práticas e o desenvolvimento de inumeráveis aplicativos voltados à edição online e ao compartilhamento das criações audiovisuais em redes socias. O YouTube, por exemplo, que é atualmente o maior site de compartilhamento de vídeos na Internet, surgiu no ano 2005 e trouxe grandes mudanças na forma de consumir, criar e compartilhar vídeos. Com o desenvolvimento da sua interface e os usos que as pessoas fazem dela, novos fenômenos e práticas emergiram, como o fenômeno YouTubers ${ }^{1}$, por exemplo. Tais redes estão mudando as práticas e a forma com que nos comunicamos, assistimos e contamos histórias com vídeos.

\section{A criação audiovisual na cultura contemporânea}

O audiovisual foi ressignificado, assim como a cultura contemporânea. “O audiovisual em particular (e a técnica em geral) revela muito sobre a cultura em que ele emerge e que ele transforma" (MONTAÑO, 2015, p. 18). A crescente utilização de aplicativos não atingiu somente a cultura audiovisual, mas toda a sociedade. A cultura da mobilidade - da multiplicidade, do hibridismo, da conexão e da volatilidade - proporcionou mudanças nos

\footnotetext{
${ }^{1}$ Os YouTubers são usuários da Plataforma "YouTube" que usam a Web para expôr as suas ideias referentes aos acontecimentos, mostram o seu cotidiano, partilham conhecimento, entretêm, e se tornam formadores de opinião e referências para a sociedade.
} 
usos, nas práticas e nos costumes. Estamos em conexão constante com os dispositivos móveis, nosso corpo flutua pelo ciberespaço, em canais, transmissões e closes.

Sem a exigência de conhecimentos técnicos dos praticantes, a produção audiovisual foi naturalizada. Os aplicativos desenvolvidos para a produção, edição e publicação de vídeos são incontáveis, tornando crescente e promissor o mercado do audiovisual "amador". Avançamos consideravelmente da filmadora para os mais modernos dispositivos móveis. Colocamos a palavra amador entre aspas, pois os limites entre o vídeo amador e o vídeo profissional são reconfigurados com a democratização do acesso aos softwares que antes eram exclusivos e hoje são aplicativos - intuitivos e gratuitos na maior parte dos casos - e das câmeras acopladas aos celulares, que atingiram a mesma qualidade de algumas câmeras digitais.

A pesquisa de Tomé e Soares $(2015$, p. 278$)$ indica que a terceira atividade mais comum dos jovens na internet é ver vídeos (76\%), a primeira foi relacionada a trabalhos escolares (85\%) e a segunda a jogos (83\%). E nem todos esses vídeos são profissionais, muitos são elaborados por praticantes ciberculturais, na mesma horizontalidade dos que estão assistindo, em uma relação de produção, mixagem, compartilhamento e visualização.

Os vídeos fazem parte dos hábitos, costumes e subjetividade do sujeito no ciberespaço, ou, como conceitua Machado (2002), do Interator, aquele que interage com aplicativos e com o mundo digital, obtendo resultados, mesmo que não conheça especificidades técnicas e de programação. É interessante pensar que esse sujeito hoje em dia, além de imergir na simulação, cria e se autoriza.

\footnotetext{
Assim, podemos pensar o vídeo digital como o mais contemporâneo de todos os vídeos, pelo potencial de atrair e transformar, ou melhor devorar todas as imagens anteriores a ele e, dessa forma, pensá-las e explorá-las. Arlindo Machado (2007 b) destaca na imagem digital a sua extraordinária capacidade de metamorfose, já que se pode nela intervir infinitamente, subverter seus valores cromáticos, inverter a relação entre figura e fundo, tornar transparentes os seres que ali aparecem. $\mathrm{O}$ autor constata que as imagens estão migrando o tempo todo de um meio a outro, de uma natureza a outra (pictórica, fotoquímica, eletrônica, digital), a ponto de este trânsito permanente se tornar sua característica mais marcante (MONTAÑO, 2015, p. 39-40)
}

A autora utiliza a palavra devorar para a combinação de imagens; concordamos com ela, indo além, já que, na cibercultura, o potencial agregador do audiovisual foi ampliado de 
diferentes imagens para diferentes tecnologias e mídias. A produção audiovisual em rede e a convergência de mídias estão relacionadas, nas produções de hoje, à utilização de variados formatos ao mesmo tempo, com técnicas específicas que mudaram os referenciais de narrativas e de roteiro. Ficcionar e inventar, como se não mais fosse o audiovisual da verdade, mas a verdade do audiovisual, além das narrativas ficcionais, audiovisuais ficcionais, a nãolinearidade, com recortes e colagens, utilizando uma enciclopédia (web), fonte rica em informações e mídias para cortar, copiar e colar.

[...] as pistas contemporâneas espalhadas pelas audiovisualidades - conceito que indica um borrar de fronteiras entre cinema, televisão e vídeo, entre documentário e ficção, entre produtor, emissor e receptor, um deslizamento entre diferentes telas (da sala escura ao celular), em qualquer lugar, a qualquer hora, o que amplia e diversifica as possibilidades do audiovisual na invenção de sujeitos e de mundos (SOARES et al., 2016, p. 136).

Trabalhar o vídeo pela perspectiva das pistas não foi uma opção preestabelecida; foi natural, talvez amparada pelas construções metodológicas delineadas na pesquisa, pela opção de aflorar as experiências coletivas ordinárias e pela observação das múltiplas telas, de gravações com os celulares como uma prática comum entre os praticantes da pesquisa, bricolando sentidos outros. A potencialidade da expressão, no criar, narrar e dramatizar ganha corpo com as audiovisualidades, com a possibilidade de produzir imagens em movimento, na escolha da fotografia, dos sons e dos textos.

Soares (2016) acredita que o limiar das audiovisualidades está "embaçando fronteiras entre códigos imagéticos, gêneros e produção-consumo e ampliando as possibilidades para a criação de conhecimentos" (p. 80) e que nos tempos em que vivemos, somos "simultaneamente, público e produtores, emissores e receptores de audiovisuais" (p. 83). Ou seja, pensar a criação audiovisual na cultura contemporânea é pensar as audiovisualidades considerando a produção de narrativas com o digital em rede. Mais especificamente, pode ser considerada a mixagem de recursos para a narração da história e realização da Digital Storytelling em formato de vídeo.

Buscamos a criação de audiovisualidades como experiência, para os nossos praticantes serem os protagonistas de suas narrativas, em suas verdades, sobre sua formação docente e suas vivências, compreendendo que não há diferença entre os múltiplos cotidianos escolares e a vida, uma não está apartada da outra, a vida está acontecendo, fluindo. É a possibilidade 
de criação e de autoria desses sujeitos que nos interessa, proporcionada atualmente pela convergência de softwares dos dispositivos móveis, disponíveis a esses sujeitos para usos diversos, criativos e com muita potência.

\section{Sobre pesquisar na cibercultura}

A cibercultura, cultura contemporânea mediada pelo digital em rede na tessitura entre a cidade e o ciberespaço (SANTOS, 2014), é a forma como lidamos, tratamos e interagimos a partir das tecnologias digitais, com interfaces e dispositivos para a produção de sentidos e autorias em rede. Por essa perspectiva, os praticantes são produtores de subjetividades múltiplas que acontecem no ciberespaço, entre elas, destacamos as práticas de docência e formação online. Elas foram se intensificando com os usos cada vez mais frequentes das tecnologias no cotidiano, como um fenômeno da cibercultura (SANTOS, 2014).

Assim como a educação, a pesquisa também acompanhou os movimentos contemporâneos. Não poderíamos estar estanques ao que se passa na cultura e promover uma pesquisa que não considerasse as práticas e os usos atuais. Amaral (2010, p. 05) contextualiza que "em 2000, Hine propôs que a Internet enquanto objeto de estudo tende a ser elaborada conceitualmente sob dois modelos de abordagem teórica: Internet enquanto cultura e enquanto artefato cultural". Nossos pressupostos de pesquisa tratam a internet enquanto cultura, concordando com a abordagem descrita por Amaral (2010, p. 05), que "Enfoca o contexto cultural dos fenômenos que ocorrem nas comunidades e/ou mundos virtuais", no nosso caso, considerando as especificidades da educação online.

A pesquisa-formação situa-se no paradigma da epistemologia das práticas. Santos, no seu livro Pesquisa-formação na cibercultura (2014), apresenta um marco teórico nesta sustentação epistêmica. Autores como Nóvoa, Tardif, Macedo, Sacristán, Josso, Ardoino e Freire são referências em estudos que não separam formação de cultura e de experiências de vida. A epistemologia das práticas reconhece o saber oriundo e reconstruído nas práticas docentes, pois, a experiência docente e toda a produção de saberes em torno dela são o objeto de estudo e motor de inspiração, "nesses estudos, interessa saber como os professores integram esses saberes a suas práticas, os produzem, transformam e os ressignificam no seio do seu trabalho" (D'ÁVILA, 2008, p. 33-34). 
Portanto, é vital entender a prática docente para além da racionalidade técnica, mas sim como uma fonte de conhecimentos e lugar privilegiado para fazer pesquisa. Aqui reside um dos maiores desafios de optar pela ciberpesquisa-formação, já que as práticas formativas nos espaçostempos da cibercultura articulam-se no próprio movimento das redes, da mobilidade e ubiquidade dos dispositivos móveis, das experiências de leitura e escrita na hipermídia. Práticas que mudam, que inovam e que inspiram novas práticas. Essa é a dinâmica que caracteriza nosso tempo. E, com esse desafio, lidamos no cotidiano do nosso campo, fazendopensando práticas formativas na cibercultura, o que implica imersão e utilização das tecnologias digitais como artefatos culturais das práticas.

Tendo este entendimento da prática docente, a pesquisa-formação multirreferencial, como método de pesquisa, não separa pesquisa de ensino. Nesta forma "outra" de pesquisar existe uma ação deliberada de transformação da realidade, já que a pesquisa-formação possui um duplo objetivo: transformar a realidade e produzir conhecimentos relativos a essas transformações. Ou seja, enquanto lecionamos em contexto de educação online, estamos pesquisando e todos os envolvidos estão sendo investigados nesse processo cibercultural. Não há centralidade no docente, nos conteúdos, nas tecnologias e nem nos praticantes, a centralidade está na rede que se forma entre todas essas interlocuções.

Uma pesquisa-formação multirreferencial não dá voz ao outro, nem tem acesso à compreensão do outro. Lançamos mão de dispositivos formativos que são criados em conjunto pelo docente e estudantes, visando à produção de conhecimentos e à reestruturação de sua prática (NÓVOA, 2004). Assim, a partir da imersão no campo, atividades disparadoras são acionadas como dispositivos. Assumimos o conceito de dispositivo a partir de Ardoino (2003), como "modos e meios utilizados pelos sujeitos para expressar noções necessárias ao pesquisador para compreender os fenômenos" (MARTINS, 2017). Esses dispositivos são, na verdade, táticas (CERTEAU, 2012) singulares que os sujeitos fazem nos cotidianos para lidar com os dilemas vivenciados em sua docência. A partir desses dispositivos, narrativas, imagens e sons emergem como fruto de autorias e coautorias do processo formativo vivenciado pelos atores da pesquisa.

Utilizamos, ao longo das pesquisas, oficinas, diários de pesquisa, grupos em mídias sociais, videogravações do campo, conversas cotidianas e interações online. Analisamos registros e narrativas. Esses dados podem ser textos, vídeos, imagens, sons e diversas 
comunicações, que emergem das ambiências formativas na cibercultura.

No presente texto, detalharemos o dispositivo que emergiu da pergunta disparadora "Como a tecnologia digital chegou na minha vida?", acionado no segundo semestre de 2015, na disciplina Tecnologias e Educação, da Licenciatura em Pedagogia da Universidade do Estado do Rio de Janeiro (UERJ), com o objetivo de vivenciar experiências de autoria durante a formação de professores na educação superior, com a criação da Digital Storytelling em formato de vídeo. Sobre ele serão as próximas reflexões.

\section{Como a tecnologia digital chegou na minha vida?}

Partimos da ideia que narrar a própria vida pode ser um dispositivo fecundo e formativo. Na realidade, fazemos isso com frequência na oralidade, no dia a dia, quando narramos histórias e lembranças de viagens, por exemplo, ou quando contamos nossa experiência sobre algum aprendizado, visita ao museu, impressões que tivemos de algum filme que assistimos, entre tantas outras coisas. Nosso eu e nosso olhar subjetivo atravessam constantemente as impressões sobre todos assuntos que de alguma maneira chegam, passam e tocam nossas vidas. Dar valor à experiência e às vivências pessoais e construir a partir delas relatos formativos foi uma das ideias centrais para desenvolver e criar este dispositivo.

Foi assim que fomos nos inspirando para a realização da Digital Storytelling em formato de vídeo, seguindo a base metodológica proposta por Lambert, que propõe a narração da história com uma variedade de componentes digitais (fotografias, imagens, texto escrito, vídeos etc. ), mixando esses recursos e criando um vídeo de até 4 minutos de duração, sempre com a voz em off do narrador. O processo de criação das histórias digitais foi iniciado a partir da pergunta disparadora: como a tecnologia digital chegou na minha vida?

Para começar a pensar na criação das histórias digitais trouxemos inspirações diversas como crônicas, vídeos e filmes. Seguindo os 7 passos que Joe Lambert propõe na metodologia, fomos apresentando os componentes básicos de uma história nas nossas aulas presenciais. Os estudantes se dividiram em duplas e trios para a realização dos vídeos. O projeto durou aproximadamente um mês e meio e poderia ser descrito em três momentos constitutivos:

$1^{\circ}$ - Escrita do roteiro da história digital.

$2^{\circ}$ - Busca por materiais e recursos (imagens, música, fotografias, vídeos etc.) e edição. 
$3^{\circ}$ - Exposição do vídeo em sala de aula presencial e no nosso grupo da disciplina no Facebook que narra como foi o processo criativo.

Trabalhamos a escrita do roteiro em várias aulas, porém, antes de começar com esse processo de escrita, assistimos ao filme "Saneamento Básico - o filme"2, do diretor Jorge Furtado. A história ficcional do filme traz um passo-a-passo da criação de um roteiro, direção, montagem, e elementos essenciais para conhecer como se dá este processo de criação no interior de uma produção audiovisual, o que foi de grande inspiração para as histórias da turma.

Além do filme, também trabalhamos com alguns sites que aprofundam na construção da escrita e roteiro da história. Partimos da proposta que, para narrar a chegada da tecnologia digital na própria vida, pode-se criar um personagem ficcional, contar uma experiência vivida, inventar uma ficção ou misturar todas essas opções numa invenção original. O mais interessante desse momento foi o entusiasmo dos praticantes culturais na sala de aula. Passamos essa aula conversando de grupo e grupo e ouvindo as "possíveis histórias" que seriam criadas e as ideias eram muito boas!

Após a escrita dos roteiros começamos a pesquisa dos softwares de edição de vídeo: nossa proposta foi utilizar o MovieMaker ou iMovie, que são softwares de edição simples e que, após a edição, permitem a possibilidade de colocar o vídeo na rede social YouTube. Mas alguns estudantes queriam narrar a história com uma estética de animação e para isso procuraram diversos softwares e aplicativos na web, como foi o caso do PowToon ${ }^{3}$, uma plataforma da web 2.0 que permite a edição de animações.

O mais interessante neste processo é que todas as histórias foram bem diferentes, mas conseguiram narrar como a tecnologia foi chegando na vida pessoal deles ou dos personagens inventados que, de alguma maneira, também falavam deles mesmos.

\footnotetext{
${ }^{2}$ No filme, que se passa numa pequena cidade do Rio Grande do Sul, um grupo de moradores está com um problema sério na rede de esgoto da cidade. Há anos recorrem à prefeitura local para a construção de um fosso, mas não recebem resposta nem solução ao problema. Certo dia, descobrem uma verba no valor de $\mathrm{R} \$ 10$ mil dada ao município para a produção de um curta-metragem fictício de cunho educativo e resolvem criar o filme sem nenhuma experiência na área.

${ }^{3}$ PowToon: https://www.powtoon.com/
} 
Na Digital Storytelling de Raphaela, Marisa e Maria Luiza, chamada $\mathbf{O}$ avanço da tecnologia: história da Renata ${ }^{4}$, é narrada a vida da Renata que passou por várias transformações até conseguir o emprego que desejava. A narradora da história nos conta como eram os costumes quando Renata era adolescente, vinte anos atrás, quando falava pelo telefone fixo com amigos e não podia contar seus "segredos", porque o telefone ficava no local público da casa e, também, como assistia TV sem puder mudar a programação quando estava sentada no sofá. Para remeter ao passado, as alunas utilizaram um filtro em preto e branco no vídeo.
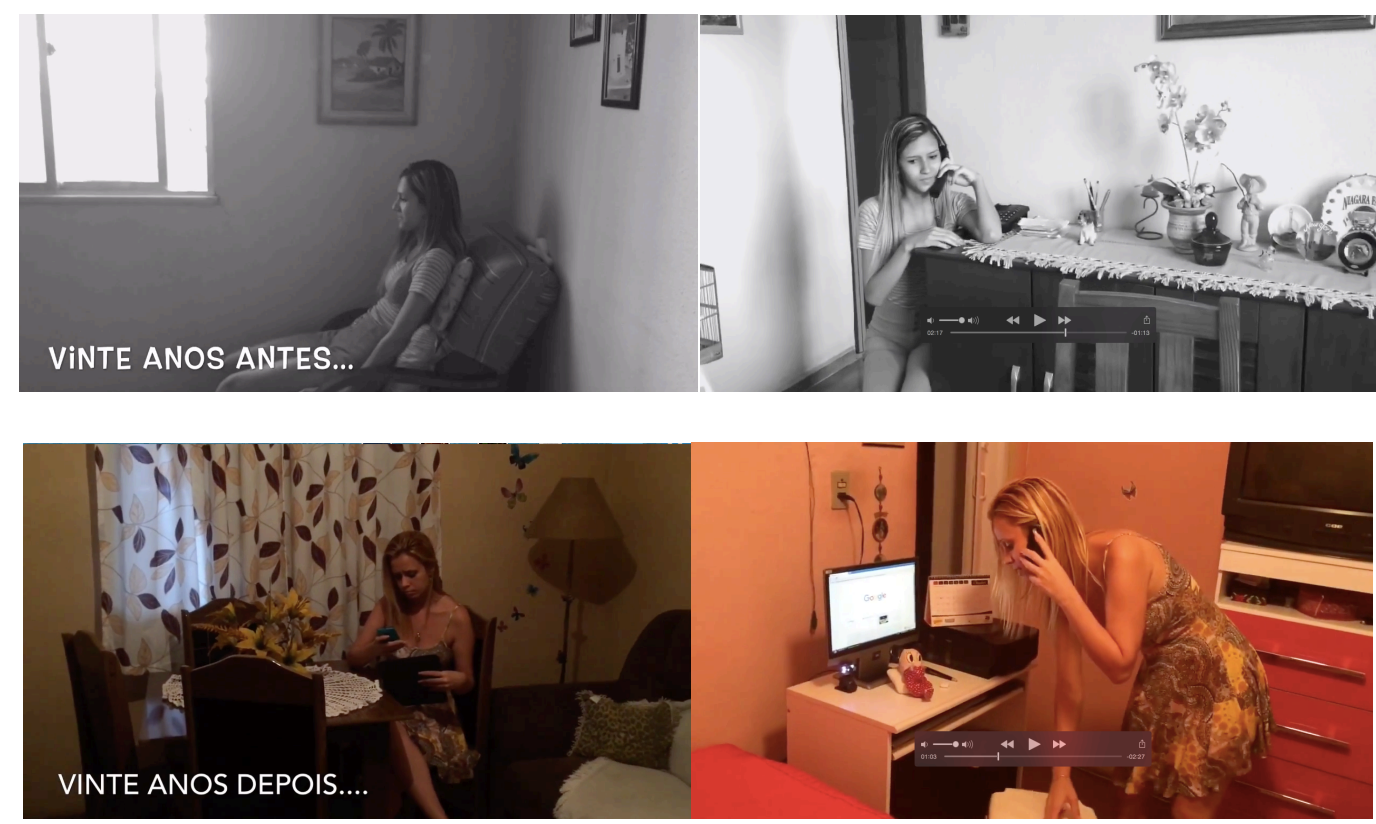

Figura 2. Digital Storytelling "história da Renata" Fonte: https://www.youtube.com/watch?v=NMI90nPXyqI\&feature=youtu.be

O mais interessante é que a Renata jovem foi protagonizada por Marisa e a Renata adulta pela mãe da Marisa, envolvendo, assim, a família e os espaços do cotidiano delas para protagonizar o vídeo.

\footnotetext{
${ }^{4}$ Disponível em: https://www.youtube.com/watch?v=NMI90nPXyql\&feature=youtu.be
} 
- Maria Luiza Schuaste com Raphaela Novello e Marisa Torres.

31 de outubro de 2015

Olá turma!!! Finalmente consegui subir o vídeo para o youtube.Foi a minha maior dificuldade, pois a internet não ajudou muito.Foi criado,produzido e editado com muito carinho espero q gostem!! A escolha da música foi proposital, a música feel so clone do Calvin harris em tradução livre significa: Eu me sinto tão perto de você agora. Essa frase traduz um pouco o que a tecnologia faz,Afinal com ela todos ficamos "perto"

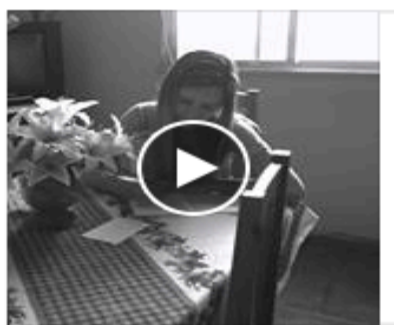

\section{O avanço da tecnologia: história da} Renata

http://youtu.be/NMI90nPXyql

YOUTU.BE
is Curtir
Comentar
Compartilhar

Você, Edmea Santos, Alice Costa e outras 13 pessoas

$\checkmark$ Visualizado por 59

Ver mais 10 comentários

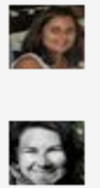

Alice Costa Olá Maria Luiza Schuaste, Raphaela Novello e Marisa Torres, a digital storytelling de vocês ficou muito bacana!

Curtir - Responder - $132 \cdot 16$ de novembro de 2015 às 19:11

Lena Chianello Mito boa abordagem, parabéns meninas! show!!! Curtir - Responder - 13 - 17 de novembro de 2015 às 00:20

Figura 3. Comentário sobre a Digital Storytelling Fonte: pesquisa de campo.

A escolha por personagens e histórias ficcionais foi a preferência da turma. A Digital Storytelling de Soyane e Raquel, chamada Digital Storytelling na UERJ ${ }^{5}$, conta a história de duas crianças tímidas que se conheceram na escola, após sofrerem uma situação de bullying digital por colegas de turma, e decidem criar um Blog em repúdio. Idas à biblioteca, conversas e criações na internet foram algumas das estratégias utilizadas para superar a problemática. As alunas protagonizaram a própria história, atuaram nela e a totalidade do vídeo foi filmada no espaços da UERJ.

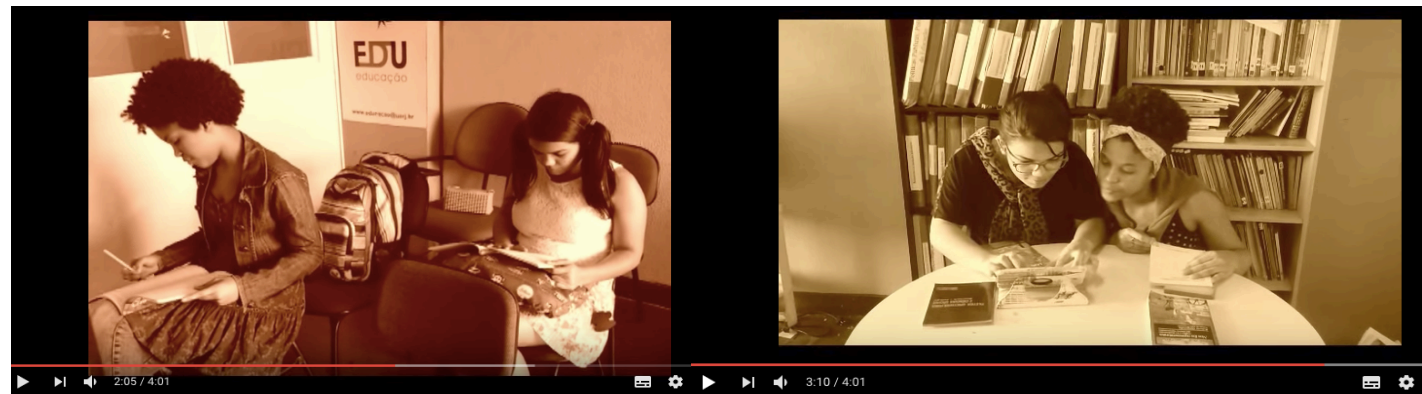

Figura 4. Digital Storytelling de Soyane e Rachel

Fonte: https://www.youtube.com/watch?v=RT6H23aWjVY

\footnotetext{
${ }^{5}$ Disponível em: https://www.youtube.com/watch?v=RT6H23aWjVY
} 
Podemos observar nesta criação como foram utilizados vários recursos para fazer a filmagem. Tem cenas gravadas com o celular (em vertical) e outras com uma câmera em horizontal, a maior dificuldade das alunas foi a edição do som. Para não terem problemas de subir o vídeo no YouTube e para que não fosse bloqueado pelos direitos autorais da música escolhida, elas resolveram criar também uma música, composta e interpretada pela aluna Soyane no piano.

Soyane Santos

28 de outubro de 2015

A construção de nosso vídeo foi muito divertida. Inicialmente iriamos fazer uma animação, construímos o roteiro e decidimos gravar as cenas.Desenhamos a mão e tiramos fotos, parte por parte e na hora da edição iriamos dar o movimento para o nosso desenho. Só que quando fomos fazer a parte da edição percebemos que não estava dando certo e mudamos de ideia.Decidimos então gravar tudo de novo só que nós seriamos os personagens e aproveitamos o roteiro.

A parte em que tivemos mais dificuldade foi na hora de organizar o áudio, a música e as filmagens.

Decidimos fazer tudo autoral,para não dar nenhum problema, a música que colocamos eu mesma compus. Raquel Isabella https://www.youtube.com/watch?v=RT6H23aWjVY

It Curtir Comentar

Você, Edmea Santos, Larissa Cristina e outras 19 pessoas $\quad \checkmark$ Visualizado por 74 Ver mais 12 comentários

Q Vitória Rodrigues Muito bom, meninas! Amei o video, a interpretação, tudo! Parabéns!! Curtir - Responder - 1 de novembro de 2015 às 11:32

Tania Lucía Maddalena Soyane Santos e Raquel Rosse parabéns pelo trabalho! Está muito bom! (:) Vocês conseguiram articular muito bem as partes centrais do Digital Storytelling, a composição da história (com suas partes, conflitos, resolução) e dos personagens, a narrativa em voz em off, a atuação de vocês mesmas ficou show!, a composição da música no piano, e o próprio conteúdo da história da tecnologia na suas vidas/personagens da história.

Fiquei feliz de saber que esta construção foi um processo divertido para vocês, espero que tenham aproveitado e aprendido muito com a experiência! Novamente parabéns!

Curtir - Responder + 8 de novembro de 2015 às 16:17

Figura 5. Narrativa do processo de criação Fonte: Grupo da disciplina Tecnologias e Educação no Facebook.

No vídeo de Soyane e Raquel também teve a participação de Isabella, que embora não pertencesse ao grupo, atuou como professora das crianças no vídeo. Esta troca não foi somente neste grupo, mas aconteceu em várias Storytelling. Acreditamos que isso muito se deve às ideias de roteiros que foram compartilhadas entre os grupos. Ao propor esse momento, incentivamos a troca e o compartilhamento de inspirações e recursos ao longo de todo o processo criativo. 


\section{Algumas considerações}

A singularidade de contar histórias foi ressignificada com as potencialidades da cibercultura. Novos usos e práticas com tecnologias instituíram a Digital Storytelling como uma proposta viável para pensar a formação de professores na educação superior, principalmente na tessitura entre memória e vivências com tecnologias digitais, foco do dispositivo de pesquisa acionado com a turma de Tecnologias e Educação.

Durante o trabalho buscamos abordar a Digital Storytelling como uma prática de contar histórias digitais em hipermídia, onde contextualizamos historicamente a metodologia, até chegar aos elementos principais de Lambert (2009) para pensar as narrativas digitais em formato de vídeo, utilizados na pesquisa para a produção audiovisual. Trazemos o entrelaçamento entre a criação audiovisual e a cultura contemporânea, com a reflexão sobre as audiovisualidades, de forma a compreender o cotidiano com os vídeos e as produções dos praticantes.

Pensando os princípios da pesquisa, apresentamos brevemente a pesquisa-formação na cibercultura como o método escolhido para o trabalho, de forma a pesquisar no contexto da práxis docente. A partir de inquietações de professores e questões de pesquisa, são desenhadas ambiências formativas ou dispositivos de pesquisa que promovam narrativas e usos pelos praticantes para ajudar na compreensão do fenômeno em questão. O campo de pesquisa foi relatado iniciando com a pergunta disparadora "Como a tecnologia digital chegou na minha vida?", apresentando os resultados em forma de vídeos, que conversavam com as narrativas oriundas do grupo da turma no Facebook.

Ao longo desse texto, destacamos os avanços da Digital Storytelling, principalmente como construção de narrativas de si de professores em formação. Valorizamos as experiências e as vivências ao longo da educação superior como algo que marcará a vida profissional e pessoal de cada praticante. Futuros professores ou profissionais da educação implicados com as tecnologias e com os vídeos, em especial, podem ser marcados por esses atos de currículo e atuar como multiplicadores em seus cotidianos. Afinal, a produção audiovisual atua como um registro de momentos de formação e como possibilidade de eternizar significações. 


\section{Referências}

AMARAL, Adriana. Etnografia e pesquisa em cibercultura: limites e insuficiências metodológicas. Revista USP, São Paulo, n. 86, p. 122-135, junho/agosto, 2010.

ARDOINO, Jacques. Para uma pedagogia socialista. Brasília: Plano, 2003.

BRUNER, Jerome. Realidad mental y mundos posibles. Barcelona: Gedisa, 1998.

CERTEAU, Michel de. A invenção do cotidiano: 1. Artes de fazer. 20. ed. Tradução: Ephraim Ferreira Alves. Petrópolis, RJ: Vozes, 2012.

D’ÁVILA, Cristina. Formação docente na contemporaneidade: limites e desafios. Revista da FAEEBA: Educação e Contemporaneidade, Salvador, v. 17, n. 30, p. 33-43, jul./dez. 2008.

JOSSO, M. C. Experiências de vida e formação. São Paulo: Cortez, 2004.

LALUEZA, José L.; CRESPO, Isabel; CAMPS, Silvia. As tecnologias da informação e da comunicação e os processos de desenvolvimento e socialização. In: COLL, C.; MONEREO, C. Psicologia da Educação Virtual: aprender e ensinar com as tecnologias da informação e da comunicação. Porto Alegre: Artmed, 2010.

LAMBERT, Joe. Digital Storytelling: capturing lives, creating community. Berkeley: Digital Diner Press, 2009.

MACHADO, Arlindo. O Sujeito no Ciberespaço. In: AIDAR, José Luiz (Org.). Crítica das Práticas Midiáticas. São Paulo: Hacker, 2002.

MADDALENA, Tania; SEVILLA PAVÓN, Ana. El Relato Digital como propuesta pedagógica en la formación continua de profesores. Revista Iberoamericana de Educación, n. 65, p. 149-160, jul. 2014. Disponível em: <http://www.rieoei.org/rie65a09.pdf> Acesso em: 15 abr. 2017.

MARTINS, Vivian. Os cibervídeos na educação online: uma pesquisa-formação na cibercultura. 2017. 179f. Dissertação (Mestrado em Educação) - Faculdade de Educação, Universidade do Estado do Rio de Janeiro, Rio de Janeiro, 2017.

MILLER, Carolyn Handler. Digital Storytelling: A creador's guide to interactive entertainment. 2. ed. New York: Focal Press, 2008.

MONTAÑO, Sonia. Plataformas de vídeos: apontamentos para uma ecologia do audiovisual da web na contemporaneidade. Porto Alegre: Sulina, 2015. 
NÓVOA, Antonio. Prefácio. In: JOSSO, M. C. Experiências de vida e formação. São Paulo: Cortez, 2004. pp. 11-34.

SANTOS, Edméa. Pesquisa-formação na cibercultura. Lisboa, Portugal: Whitebooks, 2014.

SOARES, Maria da Conceição Silva. O audiovisual como dispositivo de pesquisas nos/com os cotidianos das escolas. Revista Visualidades. Goiânia, v. 14, n. 1, p. 80-103, jan./jun. 2016.

SOARES, Maria da Conceição Silva et al. Corpos à flor da tela: audiovisualidades, gênero, sexualidade e formação de professoras. In: AMARO, Ivan; SOARES, Maria da Conceição Silva (orgs.). Tecnologias digitais nas escolas: outras possibilidades para o conhecimento. Petrópolis, RJ: DP et Ali, 2016, v. 1, p. 135-156.

TOMÉ, Vítor Manuel Nabais; SOARES, Maria do Carmo Tomé. Educação para os media: atividades de análise e produção de mensagens media na disciplina de português. In: ROSADO, Luiz Alexandre da Silva; FERREIRA, Giselle Martins dos Santos (Org.). Educação e tecnologias: parcerias. Rio de Janeiro: Editora Universidade Estácio de Sá, 2015, v. 4, p. 259299. 